INDEPENDENT JOURNAL OF MANAGEMENT \& PRODUCTION (IJM\&P)

http://www.ijmp.jor.br

v. 12, n. 5, July-August 2021

ISSN: 2236-269X

DOI: 10.14807/ijmp.v12i5.1445

\title{
INSTITUTIONALIZATION IN SERVICE PROVIDING COMPANIES: ANALYSIS IN RECRUITMENT AND SELECTION CONSULTANCIES
}

(R\&S)

\author{
Carla Milena Lordêlo Chaves \\ Sergipe School of Business and Administration, Brazil \\ E-mail: carlalordelo@hotmail.com
}

Maria Conceição Melo Silva Luft Federal University of Sergipe (UFS), Brazil

E-mail: ceicamelo.ufs@gmail.com

Ronalty Rocha

Universidade Federal de Sergipe (UFS), Brazil

E-mail: ronaltyrocha@gmail.com

Submission: 9/8/2020

Revision: 9/18/2020

Accept: 10/13/2020

\section{ABSTRACT}

Research supported by institutional theory contributes to organizational studies because they insert variables such as shared values, search for legitimacy, and isomorphism in the analysis of relationships between organizations and between organizations and the environment. In this context, this article aims to analyze the stages of institutionalization in consulting companies providing services in the recruitment and selection of people (R\&S). A qualitative-descriptive study was performed with six recruitment and selection consultancies located in Sergipe. The results demonstrated the administrative functioning of organizations about the stages of institutionalization, revealing an institutional scenario for these service providers, besides highlighting the main obstacles to the sedimentation of the companies analyzed.

Keywords: Institutional theory; habitualization; objectification; sedimentation; recruitment and selection consultancies $(R \& S)$ 
DOI: 10.14807/ijmp.v12i5.1445

\section{INTRODUCTION}

Different theories and approaches help in the process of analysis, evaluation, and implementation of improvements in organizational techniques, strategies, and structures, among them the institutional theory deserves to be highlighted, because, among other possibilities, it allows identifying environmental influences and organizational structures that contribute to the creation and dissemination of behavior patterns (Nascimento et al., 2014).

On this subject, Scott (2014) explains that institutional theory originated at the end of the 19th century in studies of economics, political science, and sociology. Additionally, Suddaby (2010) adds that the pillars of institutionalist theory in the study of organizations were inaugurated by Phillipe Selznick in the work Foundations of the Theory of Organization (1948), in which the author rejects rationalist views and views institutions as independent variables. Posteriorly, the conceptual premises of organizational institutionalism were established in the works of Meyer and Rowan (1977), Zucker (1977), Meyer and Rowan (1983), DiMaggio and Powell (1983), Tolbert and Zucker (1983), and Meyer and Scott (1983).

Besides, in the field of organizational studies, management, economics, and business are the areas that present the most studies with applications of institutional theory, in which the themes organization, institutions, and change (Carpes et al., 2015) are the most worked. In addition to this understanding, Motke, Ravanello and Rodrigues (2016) highlight business economics, social sciences, and public administration as areas in evidence in this field of studies.

In this scenario, the work of Greenwood, Raynard et al. (2011) is worth mentioning, as the most cited article on institutional theory (Silva \& Crubellate, 2016; Hsu et al., 2018), while seminal studies such as Meyer and Rowan (1977), DiMaggio and Powell (1983), Friedland and Alford (1991) and Thornton and Ocasio, (1999), remain influential (Silva \& Crubellate, 2016).

Since then, institutional theory has been the main current in research for the understanding of organizations (Greenwood et al., 2008), being applied to explain the process of legitimation in institutions and the understanding of patterns and processes of organizational change, emphasizing the role of rules and conventions that influence the way organizations and society behave (Soeiro \& Wanderley, 2019).

Another way to observe and analyze institutional theory is from its processes and stages of habitualization, objectification, and sedimentation. On this subject, Tolbert and Zucker (2012) explain that institutional theory, through the institutionalization process, is a theoretical 
DOI: 10.14807/ijmp.v12i5.1445

tool to evaluate the stage of consolidation of rules, norms, and processes in organizations, that is, the more sedimented the processes, the more institutionalized and consolidated organizational practices.

In this perspective, scholars such as Thornton, Ocasio, and Lounsbury (2012) and Scott (2014) reveal that the advance in the stages of institutionalization optimizes the administrative functioning of organizations and ensures better business and performance results.

In this context of the importance of the process and consolidation of institutionalization in organizations, it is worth highlighting the role of consultancies of recruitment and selection of people, companies that attract and select employees to work in contracting organizations and that must have standards, procedures, and institutionalized techniques to properly perform their activities (recruitment and selection) and provide high-quality services.

In this direction, Balasubramanian (2014) points out that the role of consultancies in recruitment and selection of people is to make this process effective enough for the contracting company to achieve cost optimization and access to skilled labor. Also, to keep up with the market transformations caused by digital transformations, such consultancies had to improve existing resources and innovate the recruitment and selection processes of people (OwususAnsah \& Nyarko, 2014).

As a result of the information presented, this paper addressed the following research question: how are the institutionalization steps configured in consulting firms in the recruitment and selection of people? To answer this question, this study adopted the objective of analyzing the stages of institutionalization, according to the model of Tolbert and Zucker (2012), in companies providing services in recruitment and selection consulting (R\&S) of people (employees).

Specifically, this research sought to identify characteristic elements in the stages of habitualization, objectification, and sedimentation. To achieve the proposed objective, a qualitative-descriptive study was performed with six recruitment and selection consultancies domiciled in Sergipe, Brazil.

It should be noted that, in Brazil, some of the latest studies that addressed institutional theory discussed institutional pressure for accounting reform in Brazil and Colombia (Neves \& Gomés-Vilegas, 2019); described and compared institutional, strategic, and educational characteristics of government schools in Brazil (Fonseca et al., 2019) and identified the levels 
DOI: 10.14807/ijmp.v12i5.1445

of sustainability and institutionalization practices in a packaging industry (Kulak, Stefano \& Kuhl, 2019).

On the international scene, Doherty, Chen, and Alexander (2014) evaluated the relationship of franchises in China based on assumptions of agency theory and institutional theory, while Mahanani, Hariadi, and Roekhudinque (2020) sought to understand, from remuneration policies, the process of institutionalization in a university.

It is noticed, then, that although institutional theory continues to promote relevant academic debates, the latest published studies did not direct attention to the elements that make up each stage of the institutionalization process, especially in consultancies companies, reinforcing the gap for this study.

On the other hand, there is research on online recruitment and online recruitment platforms, but few local studies on recruitment and selection consultancies. Perhaps this scenario occurs because large organizations have specific sectors for the management of people performing the role of recruitment and selection, however, to meet the demand of small and medium-sized companies, consultancies with specificity in recruitment and selection were emerging, mainly because their processes can occur digitally (Oksanen, 2018), a reality found in the smallest state of Brazil with the emergence of these companies from 2010, motivating, therefore, the practical investigation of the research.

Thus, the main theoretical contribution of this study is in the presentation and discussion of elements and characteristics that determine each of the stages of habitualization, objectification, and sedimentation in consulting firms in recruitment and selection. From a practical point of view, this study offers elements and limitations inherent to each stage of institutionalization that can be evaluated and implemented by other consultancies that seek to solve internal problems, optimize the administrative and decision-making process, as well as advancing to the sedimentation stage.

\section{INSTITUTIONALIZATION: CONCEPTUAL ASPECTS}

Initially, it should be noted that the process of institutionalization occurs in organizations over time, reproducing their history, of current or former employees, of the groups and their interests, and also of the way the company adapts to its environment (Pimentel, Carvalho \& Pimentel, 2019).

Berger and Luckman (2005) complement this understanding by explaining that institutionalization is a process that develops historically, being supported by the legitimacy of 
INDEPENDENT JOURNAL OF MANAGEMENT \& PRODUCTION (IJM\&P)

http://www.ijmp.jor.br

v. 12, n. 5, July-August 2021

ISSN: 2236-269X

DOI: 10.14807/ijmp.v12i5.1445

its constituent elements. Thus, this process covers the development of practices and, rules, which include structuring and routinizing methods for the development of codes that explain the organizational context and generate future patterns of action (Thornton, Ocasio \& Lounsbury, 2012).

For Doherty, Chen, and Alexander (2014), the institutional theory focuses on the institutions and culture that shape the business environment. Moreover, the institutional approach is the purposeful action of individuals and organizations aimed at creating, maintaining, and developing institutions (Alvesson, Hallett \& Spicer, 2019).

On this subject, Aksom, Zhylinska, and Gaidai (2020) explain that, from the institutional approach, corporations operate in environments that receive different levels of pressure that encourage the adoption of appropriate and efficient behaviors, conditioning organizations to follow rational rules and directions that increase the chances of survival, protecting structures, facilitating access to resources, in addition to increasing the relevance of these companies in the business environment.

Similarly, Yang and South (2014) argue that institutional theory is essential for organizations to follow established rules, norms, and belief systems to achieve legitimacy, boost social, economic, and political resources, and improve the company's performance. Thus, institutional theory helps to examine the influence of several factors, such as the impact of sociocultural aspects and the role of stakeholders' demands on organizational practices (Yawar \& Kauppi, 2018).

In this context, Scott (2014) defends institutionalism from a sociological perspective, according to which institutions are formed and structured by regulatory, normative, and cultural-cognitive elements associated with activities and resources that enable stability and meaning to social life. In this sense, the regulatory pillar emphasizes the importance of standardization processes, the establishment of rules, monitoring, and sanctioning of activities in the functioning of institutions (Scott, 2014). Thus, institutional regulatory systems establish behaviors through the implementation of rules, supervision, corrections, and penalties.

The normative aspect highlights the social obligation and normative rules for the adoption of new structures (Palthe, 2014), inserting a prescriptive and appreciative approach in social life, emphasizing moral conceptions, and cultural conformity. Finally, the culturalcognitive pillar emphasizes the role of the cultural-cognitive elements of institutions and the 
DOI: 10.14807/ijmp.v12i5.1445

shared values that represent the nature of social reality and how meanings are constructed (Altayar, 2018).

On the other hand, it is necessary to understand that institutional theory is divided into three guidelines: the old institutional economy; the new institutional economy, and the new institutional sociology. On this subject, Dequech (2002) explains that, in the former institutional economy, the institution is the main object of analysis. In this perspective, institutional theory develops research on the relationships between individuals within organizations, investigating attitudes that produce new social realities capable of inserting and consolidating changes.

The new institutional economics, in turn, seeks to achieve competitive advantages based on management focused on efficiency, whose minimization of transaction costs is revealed as the main aspect in determining the organizational structure (Augusto, Souza \& Cário, 2014). Therefore, Costa, Sprenger, and Kronbauer (2019) explain that, from the perspective of the New Institutional Economy, the theory focuses on transaction costs and performs an institutional analysis of how agents behave in the environment in which they operate, permeated by market imperfections.

Finally, on the new institutional sociology, there is an assumption that internal organizational structures and procedures are influenced by external factors and not only by the objectives of minimizing costs. Moreover, in this institutional characteristic, organizational aspects are adjusted to increase compatibility with the environment (Costa, Sprenger \& Kronbauer, 2019).

For this reason, Tolbert and Zucker (2012) explain that institutionalization is a typification of actions usually made by specific types of actors. Thus, to understand the process of institutionalization in the organizational context, Tolbert and Zucker $(1999,2012)$ divided it into three phases: habitualization (pre-institutional), objectification (semi-institutional), and sedimentation (total institutionalization) discussed below.

\section{Institutionalization Process}

According to Tolbert and Zucker (1999, 2012), the occurrence of factors external to the organization generates the need for innovation. In response to this need, companies begin the 
DOI: 10.14807/ijmp.v12i5.1445

stage of habitualization, characterized by the search and implementation of new structural arrangements to solve specific organizational problems.

In this sense, different organizations can adopt similar innovations because they are subject to the same organizational context (Wisdom et al., 2014), stimulated by causation forces such as technological changes, legislation, and market forces (Roth, 2015).

This fact can lead to the understanding of isomorphism or imitation (Dimaggio \& Powell, 2005) when the company adopts solutions developed by other organizations because of 1) political influence and need for legitimation - coercive isomorphism; 2) standardization of responses to uncertainty - mimetic isomorphism; and 3) professionalization — normative isomorphism (Li \& Ding, 2013).

Regarding coercive isomorphism, Kaupi (2013) indicated that this modality of isomorphism is a consequence of society's expectations (Dimaggio \& Powell, 1991) and the result of the formal and informal pressures that organizations exert among themselves. In this context, organizations are pressured by different stakeholders, such as customers, government, and competitors, to absorb and implement social, environmental, and economic standards (Sarkis, Zhu \& Lai, 2011).

On the other hand, mimetic isomorphism is a consequence of the uncertainties faced by companies, which leads them to the practice of imitation. Thus, environments with a higher degree of uncertainty often model mimetic isomorphism practices (DiMaggio \& Powell, 1991). In this perspective, Miemczyk (2008) explains that mimetic isomorphism occurs among institutions seeking legitimacy, which mimic successful strategies to reduce the risk of adoption of little-explored solutions. Moreover, the dissemination of practices perceived as legitimate is typical in companies within a connected network, where the dissemination of practices is easier (Yawar \& Kauppi, 2018). Furthermore, Kaupi (2013) warns that so-called excellent practices do not offer the same results in all organizations due to contextual divergences, so mimetic isomorphism can generate unwanted results.

As for normative isomorphism, DiMaggio and Powell (2005) clarify that normative actions result from professionalization, which occurs through formal education and legitimation on a cognitive basis produced by university specialists and the network of professionals in which experts are inserted. Thus, the concept of professionalization refers to the collective struggle of the members of an occupation to define the conditions and methods 
DOI: 10.14807/ijmp.v12i5.1445

of their work, to control production, and to establish a cognitive and legitimizing basis for occupational autonomy (Altayar, 2018).

In this way, León e Martinez (2011) argue that the greatest advantage of habitualization is the increase in the predictability of actions, which can save time, effort and reduce the effects of environmental pressures, additionally, solutions tested with positive results by other organizations can stimulate imitation as a diffusion process.

The second phase of the institutionalization process is objectification, achieved when the meanings imposed on the usual action are generalized and become socially shared. This stage, which is that of semi-institutionalization, is associated with the diffusion of the structure created previously, this stage there is the valorization of the structure and its increasing adoption in organizations, assuming a permanent and disseminated character (Tolbert \& Zucker, 2012).

Also, the objectification process involves the development of social consensus among organization managers on two causative forces: inter-organizational monitoring and theorization (Greenwood, Suddaby \& Hinings, 2002).

On this subject, inter-organizational monitoring proposes that organizations can use evidence obtained from various sources to assess the risks of the adoption of new structures. In this sense, the objectification of the structure is partly a consequence of monitoring the actions of competitors and efforts to increase organizational competitiveness (Raynard, Johnson \& Greenwood, 2014). The main objective of theorization is to describe organizational failures, for which innovation is a solution (Tolbert \& Zucker, 2012).

Another relevant point in the objectification phase concerns the presence of champions, a set of actors involved with the structure, who have some degree of interest in its advancement and dissemination. Champions perform two major theorization tasks: definition of a generic organizational problem, which includes the specification of a set or category of organizational actors characterized by the problem; and justification, with logical and/or empirical bases, for the adoption of a structural arrangement as a solution (Tolbert \& Zucker, 2012).

In the last phase, that is, in sedimentation, there is a total institutionalization, because the actions acquire the condition of exteriority and are transposed to other contexts, consolidating the structure for the members of the organization (Vailatti et al., 2017).

At this stage, there should be low resistance of opposition groups, promotion, and continuous cultural support and a positive relationship as the desired results (Rezende, 
INDEPENDENT JOURNAL OF MANAGEMENT \& PRODUCTION (IJM\&P)

http://www.ijmp.jor.br

v. 12, n. 5, July-August 2021

ISSN: 2236-269X

DOI: 10.14807/ijmp.v12i5.1445

Guerreiro \& Dalmácio, 2012), therefore, the three main factors for the characterization of the sedimentation phase are the positive impacts - results associated with the structure; group resistance - people who are affected by the structure; and advocacy of interest groups - people in favor of structural change (Russo, Parisi, Megliorini \& Almeida, 2012).

\section{METHODOLOGY}

Regarding the approach, this is a qualitative study, since the results are evaluated based on the perception of the agents involved in the research (Creswell, 2010) - consultancy managers. As for the objectives, this is a descriptive study, since the description, understanding, and interpretation of existing mechanisms (Neuman, 2013) was carried out from a preestablished set of categories in the process of institutionalization in R\&S consultancies.

The strategy adopted was the study of multiple cases, since the research involved six R\&S consultancies to analyze the phenomenon and characteristics (Merriam, 1998; Yin, 2015) of institutionalization in these businesses. The criteria for the selection of consultancies were the provision of services in recruitment and selection of people; domiciled in Sergipe; highlight in the local market. Thus, considering the principle of theoretical saturation (Eisenhardt, 1989), 6 cases remained.

We used a semi-structured interview script elaborated from the literature review with the following analytical categories: characterization of consultancies and institutionalization stages, as proposed by Tolbert and Zucker $(1999,2012)$ and presented in Table 1.

Table 1: Categories and north-class issues

\begin{tabular}{l|l}
\hline $\begin{array}{l}\text { Category of } \\
\text { analysis }\end{array}$ & Guiding questions \\
\hline $\begin{array}{l}\text { Characterization of } \\
\text { consultancies }\end{array}$ & $\begin{array}{l}\text { • Is your consultancy an individual company or a business society? } \\
\text { - How long has the company been in operation? } \\
\text { - What are the main business activities in your company? }\end{array}$ \\
\hline Habitualization & $\begin{array}{l}\text { - Was there any fact external to the consultancy that led to the need for innovation? If } \\
\text { so, what happened and how did the process take place? } \\
\text { - How does the consultancy identify trends in the R\&S market? } \\
\text { - Describe how consultancy perceives external pressures. } \\
\text { - Does the company usually benchmark with other consultancies for socialization and } \\
\text { search for new knowledge? Comment on that. } \\
\text { - Are the services provided by your consultancy important to society? Do you believe } \\
\text { that your company has credibility in the community where it operates? }\end{array}$ \\
\hline $\begin{array}{l}\text { Objectification } \\
\text { regarding the problems faced or improvements obtained? How is this process done? } \\
\text { - How does the process of identifying problems in consultancy take place? Is there a } \\
\text { group that has this responsibility to monitor the market? If so, explain their performance } \\
\text { and how solutions are sought. } \\
\text { - What are the most significant improvements or changes that have occurred in your } \\
\text { consultancy? And how was organizational performance perceived after these } \\
\text { improvements/changes? }\end{array}$ \\
\hline
\end{tabular}




\begin{tabular}{l|l}
\hline Sedimentation & - Do employees believe in the company's projects and are always looking for \\
improvements? Are there or have there been groups of people who support and/or \\
defend the way your company operates? If so, what groups, why, and how do you deal \\
with it? \\
- Are there or have there been groups of people (employees/customers/competitors) \\
who resist the way your company operates? If so, what groups, why, and how do you \\
deal with it? \\
- Throughout the company's existence, has there been organizational growth? Report. \\
- How do you consider that the results achieved by the consultancy are satisfactory \\
regarding your returns (financial, customer recognition, a good relationship with \\
candidates...)? \\
- Do you consider that your consultancy is a reference in the market? If so, report the \\
trajectory.
\end{tabular}
Source: Developed by the authors (2020)

The interviews were applied and recorded in person and with the help of online tools to managers (founders) of six R\&S consulting companies located in Sergipe, who received the fictitious appointment of A, B, C, D, E, and F. For the analysis of evidence, the content analysis technique based on Bardin (2006) was used, performed as follows:

1) Pre-analysis: Hearing and transcribed the content of the interviews accompanied by a preliminary and fluctuating reading of the content reported by the managers to systematize the initial ideas exposed by the interviewees.

2) Exploration of the material: analytical reading of the transcription of the interviews with the identification and construction of categories, terms, and elements related to the practice of isomorphism and stages of institutionalization. In addition, the keywords were highlighted in each paragraph of the transcription of the interviews and, based on the theoretical framework elaborated, these terms were grouped according to themes related to isomorphism (mimetic, coercive, and normative), as well as the stages of habitualization, objectification, and sedimentation.

3) Treatment of results, inference, and interpretation: the results obtained were examined from the assumptions of institutional theory and management studies, with the corresponding comparative analysis between cases - cross-case analysis (Eisenhardt, 1989) and presentation of inferences from the researchers.

Regarding the validity of this study, Yin (2015) explains that the validity of a case study can be judged through three tests: construct validity, external validity, and internal validity. The construct validity in this research was due to the chaining of evidence reported by the entrepreneurs, as well as by reviewing the transcripts of the interviews with the key informants.

The external validity, in turn, performs analyses on the generalization of the findings in research. Because this is a qualitative study, it was verified the external validity comparing 
DOI: 10.14807/ijmp.v12i5.1445

empirical findings with theoretical postulates, as well as by the analytical generalization of the results. The internal validity is applied to quantitative studies (Yin, 2015), a methodological configuration not adopted in this research.

\section{ANALYSIS AND DISCUSSION OF RESULTS}

The description of the findings of each consultancy submitted to the study follows the order of the categories of the analysis presented in Figure 1 regarding the aspects of habitualization, objectification, and sedimentation. The first reinforces the search for isomorphic practices, environmental stimuli (technological, legislation, and market forces), and the adoption of new structural arrangements. The second depicts inter-organizational monitoring and problem theorization. Finally, the sedimentation elements sought to identify interest groups, group resistance, and positive impacts.

In this perspective, Figure 2 presents the characterization of the consultancies under investigation.

Figure 2: Characterization of companies

\begin{tabular}{|c|c|c|c|c|}
\hline Consultancy & Property & Foundation & $\begin{array}{c}\text { Activities } \\
\end{array}$ & Interviewed \\
\hline $\mathrm{A}$ & $\begin{array}{l}\text { Single } \\
\text { owner }\end{array}$ & 2015 & $\begin{array}{l}\text { Recruitment, selection, training, and } \\
\text { personnel development. }\end{array}$ & Owner \\
\hline B & $\begin{array}{l}\text { Single } \\
\text { owner }\end{array}$ & $\begin{array}{l}2017 \text { (still informal) } \\
\text { and formalized in } \\
2018\end{array}$ & $\begin{array}{l}\text { Management of results culture, } \\
\text { recruitment, and selection. }\end{array}$ & Owner \\
\hline $\mathrm{C}$ & $\begin{array}{l}\text { Single } \\
\text { owner }\end{array}$ & 2014 & Recruitment and selection. & Owner \\
\hline $\mathrm{D}$ & $\begin{array}{l}\text { Society (two } \\
\text { owners) }\end{array}$ & 2011 & $\begin{array}{l}\text { Provision of multidisciplinary health } \\
\text { services, recruitment, selection, } \\
\text { training, and development. }\end{array}$ & $\begin{array}{l}\text { Owner } \\
\text { partner }\end{array}$ \\
\hline $\mathrm{E}$ & $\begin{array}{l}\text { Single } \\
\text { owner }\end{array}$ & 2016 & $\begin{array}{l}\text { Recruitment, selection, and } \\
\text { development. }\end{array}$ & Owner \\
\hline $\mathrm{F}$ & $\begin{array}{l}\text { Single } \\
\text { owner }\end{array}$ & 2016 & Recruitment and selection. & Owner \\
\hline
\end{tabular}

Source: Developed by the authors (2020).

\subsection{Elements and phase of the institutionalization process}

Considering the institutionalization process proposed by Tolbert and Zucker (1999, 2012), this subsection aims to discuss and analyze aspects and characteristics linked to each of the stages of habitualization, objectification, and sedimentation, for the subsequent framing of these companies in stages of institutionalization.

\subsection{Habitualization}

The phase of habitualization or pre-institutionalization occurs from environmental stimuli, such as legislation, technological changes, and market forces, which lead to the practice 
DOI: 10.14807/ijmp.v12i5.1445

of isomorphisms, the development of standardized behaviors for the solution of specific problems and, consequently, give rise to new structural arrangements (Tolbert \& Zucker, 1999, 2012).

In this sense, initially sought to investigate practices of coercive, normative, and mimetic isomorphism. As for mimetic isomorphism, interviewee A reported that the company has "partnerships with municipal agencies to receive resumes, as well as the exchange of experience with similar companies". Moreover, mimetic isomorphism was identified in the speech about "closing the office and using co-working spaces or in the client's space to reduce costs and invest in constant courses and updates for our employees".

Additionally, about isomorphism practices and environmental stimuli, interviewee B stated that she does not perceive external pressures for the use of administrative techniques, processes, or strategies. Regarding the professionalization process, characterizing normative isomorphism, interview B emphasized that "in general, we participate in online or face-to-face training at least four times a year". Commenting on environmental stimuli, the interviewee of Consultancy $\mathrm{C}$ reported that the company "seeks to update itself on the market trends of digital tools in the area of R\&S through Linkedin [digital social network of business] and magazines specialized in people management".

In Consultancy D, normative isomorphism was identified in the investment in courses, updates, and continuous training of employees, as highlighted:

This is related to the way I train people. We hold regular meetings, analyze the profiles of all our employees, and draw up a list of activities that each needs to deliver and give feedback when I realize that someone needs development. When I see some training that is consistent with what someone on my team needs, I seek to insert it into our schedule. I want everyone to grow up so I can grow up with them (Interviewee D).

Beyond that, it should be highlighted that all the consultancies surveyed reported the frequent search for technological tools for adaptation of processes, which characterizes the response to technological environmental stimuli and market forces. Moreover, compliance with labor legislation, mentioned by all interviewees, is a common element of coercive isomorphism. Regarding the reaction to environmental stimuli, the interviewee of the consultancy E highlighted that "I do not perceive the performance of these pressures in my business and I prefer to act according to my knowledge", attributing little relevance to external pressures for the management of the company. 
DOI: 10.14807/ijmp.v12i5.1445

As for the generation of new structural arrangements, according to consultant A "the most significant improvements and changes that occurred in the company were the results of the implementation of technological tools, which promoted agility, clarity, and speed in the recruitment and selection processes, and also in communication within the consultancy".

Furthermore, it was noted in the statements of the interviewee of Consultancy B, that the company has been working on new structural arrangements through participation in WhatsApp groups and networking with professionals in the area of people management, as well as accounts on Instagram to discuss topics in the area. Consequently, the information obtained in these environments is redirecting, and adjusting the internal functioning of this company.

Interviewee $\mathrm{D}$ drew attention to the future implementation of new structural arrangements using her technological tools, because, according to this consultant "we seek to know the existing technological tools in the area of people management and we intend, soon, to develop our digital tools".

In consultancy E, according to the interviewee, the adoption of new arrangements was based on the "need for internal changes to meet confidential processes". Besides, she reported interest and research on market trends, especially about the use of digital tools in R\&S. In this context, the interviewee of Consultancy E reported that the expressiveness and scope of digital social networks, made the company work with the "dissemination and performance of consulting services on Instagram [which] helped the growth of the company and enabled the expansion of recruitment and selection processes".

Still related to the generation of new structural arrangements, interviewee F mentioned the "need for internal changes to meet the demands of the Consultancy with higher productivity, because we went through a transition between manual processes to the digital platform".

All the cases presented reveal that, in the habitualization phase, specifically about technological environmental stimuli, there is a frequent concern with the monitoring and implementation of digital trends for recruitment and selection (R\&S) of employees. This finding is supported by Rodríguez-Sánchez, Montero-Navarro, and Gallego-Losada (2019), who reinforce that technological innovation fostered by the use of the Internet and social networks in the business context has changed the recruitment and selection processes in organizations, allowing to select more qualified candidates and provide companies with a sustainable competitive advantage. 
DOI: 10.14807/ijmp.v12i5.1445

In this context, it is worth mentioning that the changes resulting from the imposition of legislation are presented in labor legislation (coercive isomorphism) and that, although not specifically mentioned by the interviewees, market forces encompass technological changes, since technology behaves as an imperative in these businesses.

Also concerning the habitualization stage, it was noticed that the generation of new structural arrangements was explicitly presented only in consultancies B (WhatsApp groups, networks, and Instagram accounts); And (suitability for confidential processes, Instagram account) and F (implementation of the digital R\&S platform), in other companies, the new structural arrangements are implicitly represented by the adoption of technological trends.

In summary, regarding the stage of habitualization, it was noted that in the consultancies participating in this study, internal changes occur from the identification of needs, either to adapt to the behavior of other organizations that adopt more agile and improved services and solutions, due to the need for internal adjustments to monitor the changes that happen in the area of information technology or to better meet the demands and internal processes of the company. In addition, it was noted that consultancies always act following contingencies and environmental events, not always anticipating situations, a finding that requires the attention of consultants, since the better the management of external environmental factors, the higher the level of business performance (Rizal \& Suhadak, 2017).

These results corroborate the findings of Yilmaz and Flouris (2017) and reinforce that the political, social, and cultural environment influence the definition of strategies, the adoption of structures, and the design of organizational processes in business institutions. Moreover, the results obtained expand the findings of Haider (2014) that organizations with similar environments adopt similar processes, technologies, political structures, and power relations, in the case of the companies surveyed, the similarities are expressed in the verification and implementation of digital trends in the recruitment and selection process.

Similarly, the findings identified in the researched consultancies corroborate the studies of Rees and Smith (2017) and Seyfried, Ansmann, and Pohlenz (2019) highlighting that the environmental pressures received by organizations stem from institutional mechanisms called coercive, mimetic, and normative isomorphisms, which act to make organizations more homogeneous in structural and procedural terms.

It is worth mentioning, according to the interviewees' reports, that the simultaneous practice of mimetic, coercive, and normative isomorphisms was not identified in any of the 
INDEPENDENT JOURNAL OF MANAGEMENT \& PRODUCTION (IJM\&P)

http://www.ijmp.jor.br

v. 12, n. 5, July-August 2021

ISSN: 2236-269X

DOI: 10.14807/ijmp.v12i5.1445

evaluated consultancies. Additionally, the influence of labor legislation is highlighted as an element of coercive isomorphism; the practices of participation in courses, updates, and professionalization through face-to-face and online courses, as well as the absorption of information and knowledge in digital social networks and specialized magazines, such as normative isomorphism behaviors, reinforcing DiMaggio and Powell's understanding (1983) that organizations tend to use lines of action already defined in society and that allow them to ensure their survival and legitimacy in the market.

The findings presented earlier reinforce the perception of Seyfried, Ansmann, and Pohlenz (2019), as well as Li and Ding (2013) who state that the isomorphic behavior adopted by organizations is also a form of self-defense to face environmental changes and living with problems for which solutions have not yet been found.

\subsection{Objectification}

In this category, inter-organizational monitoring and theorization were analyzed. In the inter-organizational monitoring, analyses of competing companies are performed to search for legitimate actions (Dimaggio \& Powel, 1991; Capellari, Stefano \& Castro, 2019), while the theorization process evaluates actions to solve problems (Tolbert \& Zucker, 1999, 2012).

As for the practices of inter-organizational monitoring and application of benchmarking with other consultancies for socialization and knowledge of new administrative techniques, interviewee A reported that at the beginning of the activities there was a lot of resistance and lack of openness of competing companies, but currently, this exchange happens naturally, as reported:

I have strong partners who also work in the same segment and we have come together in many moments. I have two competing companies that also do recruitment, selection, and training, but we see ourselves as partners and not as competitors. We talk a lot, exchange experiences, give tips on how to do the work (Interviewee A).

Regarding inter-organizational monitoring, especially techniques and administrative processes, interviewee $\mathrm{C}$ stated that "we do not seek this information, but I believe that it is necessary to perform [interaction with other companies], but we monitor the needs for improvement through customer feedback after the service provided. On this subject, interviewee $\mathrm{D}$ reported concern about evaluating the practices adopted by other consulting companies, she said: 
DOI: 10.14807/ijmp.v12i5.1445

[We monitor the market] for the problems faced or improvements obtained, but the Sergipe market is very closed and most companies in this segment do not work with information sharing and cooperation [...] this is a culture that still needs to be disseminated and more accepted here in the region [Sergipe] (Interviewee D).

Consultant D also stated that she is highly copied in her processes and that, although she maintains contact with reference professionals and partner companies to exchange experiences, has never adopted behaviors or strategies of competitors.

Regarding theorization, interviewee A reported that "I often [identification] the most common problems and the company has the support of some advisers, who are people outside the consultancy and who are attentive to the company's movements, providing feedback and guidance". According to interviewee $\mathrm{D}$, the process of identifying problems in the consultancy is carried out by her, however, there is the practice of involving employees. On this theorizing practice, she reported that:

Problem identification is done by me and the staff to identify the most urgent needs. In addition, we hold an annual strategic planning meeting to listen to people working in the company, as well as occasional meetings to align expectations (Interviewee D).

In consultancy E, the theorization process to identify problems occurs through the "exchange of knowledge between those involved in the execution of selection processes". In the case of consultancy F, the interviewee reported that "the identification and survey of problems are done by me, we also work with the preparation of action plans, in addition to monitoring the reactions and opinions of customers as a thermometer to identify problems".

On the objectification stage, it was noted that inter-organizational monitoring is carried out superficially, since most companies (A, D, E, and F), although with different speeches, perform only the observation of similar companies. Another fact that draws attention is the non-description of inter-organizational monitoring actions in consultancies B and C. On the other hand, it was found that the internal evaluation of problems, usually performed by entrepreneurs, is the main theorizing mechanism in R\&S consultancies, especially in companies A, B, D, E, and F.

In general, in relation to inter-organizational monitoring, the interviewees answered that there is a lot of local difficulty in this practice and that knowledge exchanges only happen when there is personal proximity between the consultancy owners. There were even reports of a lack 
DOI: 10.14807/ijmp.v12i5.1445

of confidence about the administrative techniques adopted by the competition, allowing only the eventual exchange of knowledge.

This finding is validated by Chan, Chong, and Zhou (2012), since the exchange of knowledge between organizations depends on the existence of minimum levels of trust among the managers involved to dissolve conflicts, facilitate information sharing, and strengthen longterm partnership strategies.

Regarding the theorization process, the majority reported that the problem-solving activity is concentrated in the consultancy owners. However, it is worth mentioning that the existence of external advisers (consultancy A), customer feedback (consultancy C), comparison with partner companies (consultancy E) and development of action plans based on customer feedback (consultancy F) are also actions considered in the companies surveyed.

In addition, in consultancy $\mathrm{D}$, for the theorization process, the teams are involved and give their opinion on the situation, which provides a basis for decision making. On this subject, Mutai, Cheruiyot and Kirui (2015) argue that the participation of employees in the decisionmaking and problem-solving process promotes a significant increase in the quality of decisions, in addition to improving the organizational climate.

Finally, according to the interviewees' reports, there is a simple process of identifying problems and seeking solutions, which only happens when the situation requires it. This finding requires more attention from the companies analyzed since the planning prevents organizations from being surprised by environmental events and/or contingencies capable of affecting their business (Cancellier, Blageski Junior \& Rossetto, 2014).

\subsection{Sedimentation}

Finally, there is the stage of sedimentation or total institutionalization, which is characterized by the perpetuation of the structure for a long period, by the low resistance of the opposition groups, and by the support of the members for the positive results achieved (Abeygunasekera, 2019). Tolbert and Zucker $(1999,2012)$ state that, as the stages of institutionalization progress, organizational actors establish stronger social relationships, norms and procedures are better understood, and organizational identity is widely disseminated among members (Haack, 2012).

Regarding the support of members and the advocacy of interest groups, interviewee A stated that: 
INDEPENDENT JOURNAL OF MANAGEMENT \& PRODUCTION (IJM\&P)

http://www.ijmp.jor.br

v. 12, n. 5, July-August 2021

ISSN: 2236-269X

DOI: 10.14807/ijmp.v12i5.1445

Improvements in processes with the use of digital tools are perceived by the groups involved with the company, whether partners, employees, customers, or candidates, and these groups react positively to the application of methodologies that interconnect technology and practice [...] We also have some external advisors and service providers who work with the company and are people who believe and support the company's projects, in addition to defending our way of acting (Interviewee A).

Highlighting the performance of interest groups, consultant D reported that there are groups of people who provide support and / or defend the way the company operates, she stressed that it has noticed a positive growth in the reputation of the company in the last four years, " bringing the credibility and trust of the people involved, whether customers, candidates or employees ".

Regarding the resistance of interest groups, consultant A mentioned the resistance of some groups to the way the company operates, highlighting that the lack of support comes from people who adopt more traditional professional performance. The consultant's speech, in this sense, is as follows:

For example, in our work, we always try to bring innovative things and there are professionals here in the State [Sergipe] who have this more methodical way of acting, so if there is a lot of dynamics or technology involved in the process, it ends up scaring a little and creating some resistance (Interviewee A).

Asked about possible groups of people who resist the way the company operates, interviewee $\mathrm{F}$ said she has dealt with candidates resistant to the use of the digital platform. He pointed out:

Some people think that by paying to be on the platform, the consultancy should insert it into the job market. But this is not how it works, it will depend on a set of variables, such as the effort and performance it presents when participating in a selection process, its experiences, and skills, for example. So, some people end up showing some resistance (Interviewee F).

Regarding the positive impacts perceived by interviewee A, the consultant explained that "the results achieved are adequate in terms of return in general, but in the financial aspect the projection is still not satisfactory, but we are ensuring the maintenance of activities". Regarding the perception of positive impacts, this interviewee added:

Our company is consolidated in the market and I am aware [that the company's growth] is the result of a constant process of reinventions, and as for the intention to continue 
INDEPENDENT JOURNAL OF MANAGEMENT \& PRODUCTION (IJM\&P)

http://www.ijmp.jor.br

v. 12, n. 5, July-August 2021

ISSN: 2236-269X

DOI: 10.14807/ijmp.v12i5.1445

consultancy in the long term, I believe in the growth of the company on a regional scale in the Northeast, with the participation of new partners, and market gain (Interviewee A).

On organizational growth and development as positive impacts of the business management model, interviewee B stated that "the idea is that in two years the company will make a transition to acting only with coaching techniques and executive development, no longer offering services [recruitment and selection] that are in our portfolio today."

Interviewee B also stressed that the perceived positive impacts on her business are the result of her academic-professional training and performance outside the Sergipe capital. She said that "our consultancy is the only one in the interior where we work, and because I have experience in psychology and coach, in addition to experience in large companies, I have credibility with customers and this provides business growth."

As for the positive impacts on the sedimentation stage, interviewee $\mathrm{C}$ mentioned "we are among the four most sought-after consultancies in the Sergipe market and our investment planning and strategic actions detail actions until the year 2021". On this subject, interviewee D reported that, throughout its existence, the company has experienced organizational growth, because "there has been an increase in the portfolio of customers and its loyalty shows growth, as well as the financial behavior of the company, with satisfactory results".

Interviewee $\mathrm{D}$ also stressed that there is an intention to continue consultancy in the long term and that she is reviewing the company's business model. "I'm very attuned to what's happening in the world and I've seen the need to review my business model for the company to grow independently of me," she said.

For interviewee E, the positive impacts are perceived in the credibility with its clients and in the market in which it operates, reinforcing the intention of continuity of consultancy in the long term. For her, "the processes carried out are increasingly consolidated and the future is to focus only on strategic work and not so much on operational work as it currently occurs."

For the sedimentation stage, attention is drawn to the fact that consultancies B, C, and E do not identify groups of resistance to the operation of these businesses, allowing us to infer that these companies have directed little attention to the recognition of these groups, which is harmful because the resistance of the groups prevents the perpetuation of good results and the consolidation of new structures (Sornberger et al., 2019).

Thus, in general, customers, candidates, and employees are among the resistance groups in the other companies consulted. A similar situation is detected in the identification of interest 
DOI: 10.14807/ijmp.v12i5.1445

groups in which customers, employees, candidates, and service providers (Donadone, Silveira \& Ralio, 2012) were the most mentioned.

In this context, it is worth mentioning that the joint action of customers, candidates, and employees is essential for the consolidation and sedimentation of companies because the appropriate interaction between these groups stimulates innovation, customer loyalty, the development of products and services and improves financial results (Subramanian, 2018). Moreover, it is worth highlighting the essential role of customers for the growth and sedimentation of the business, whether as defense agents of the company and members of interest groups, since, in addition to buying more, customers function as a network to reach other potential consumers, sharing experiences (Hague \& Hague, 2016.)

In relation to the positive impacts perceived by the entrepreneurs consulted, the organizational growth of the companies stands out, mainly represented by the increase in the number of clients served. On this subject, Khadka and Maharjan (2018) explain that the company's growth is not only supported by the increase in the number of customers served, but mainly by offering innovative and quality products and services.

\subsection{Institutionalization in Recruitment and Selection Consultancies (R\&S)}

A higher incidence and/or absence of elements and practices were found in the evaluated consultancies that allowed the framing of these businesses in the phases of habitualization, objectification, and sedimentation. Thus, consultancies B and C were classified in the habitualization phase, because despite presenting elements of the following steps, they do not develop inter-organizational monitoring actions, demonstrating that they are not yet objectified.

Companies D and E, in turn, can be classified as objectified, because although they present some components of the sedimentation phase, they have not yet identified groups of resistance to the operation of the business, nor have they built strategies to mitigate the resistance of these groups (after their probable appearance).

It is worth highlighting the situation of company $\mathrm{F}$, which, although it presents elements belonging to all stages of institutionalization, was framed in the objectification phase, because, with the recent adoption of the digital tool for recruiting and selecting people, it has not yet built a generalized organizational identity among members and interest groups (Haack, 2012). Finally, company A was the only one in the sedimentation phase, as it has robust elements and characteristics of all stages of institutionalization. 
INDEPENDENT JOURNAL OF MANAGEMENT \& PRODUCTION (IJM\&P)

http://www.ijmp.jor.br

v. 12, n. 5, July-August 2021

ISSN: 2236-269X

DOI: 10.14807/ijmp.v12i5.1445

The synthesis of the results obtained in the companies surveyed is presented in Figure 1, which presents an analytical structure with the main practices and elements of the institutionalization stages in recruitment and selection consultancies domiciled in Sergipe.

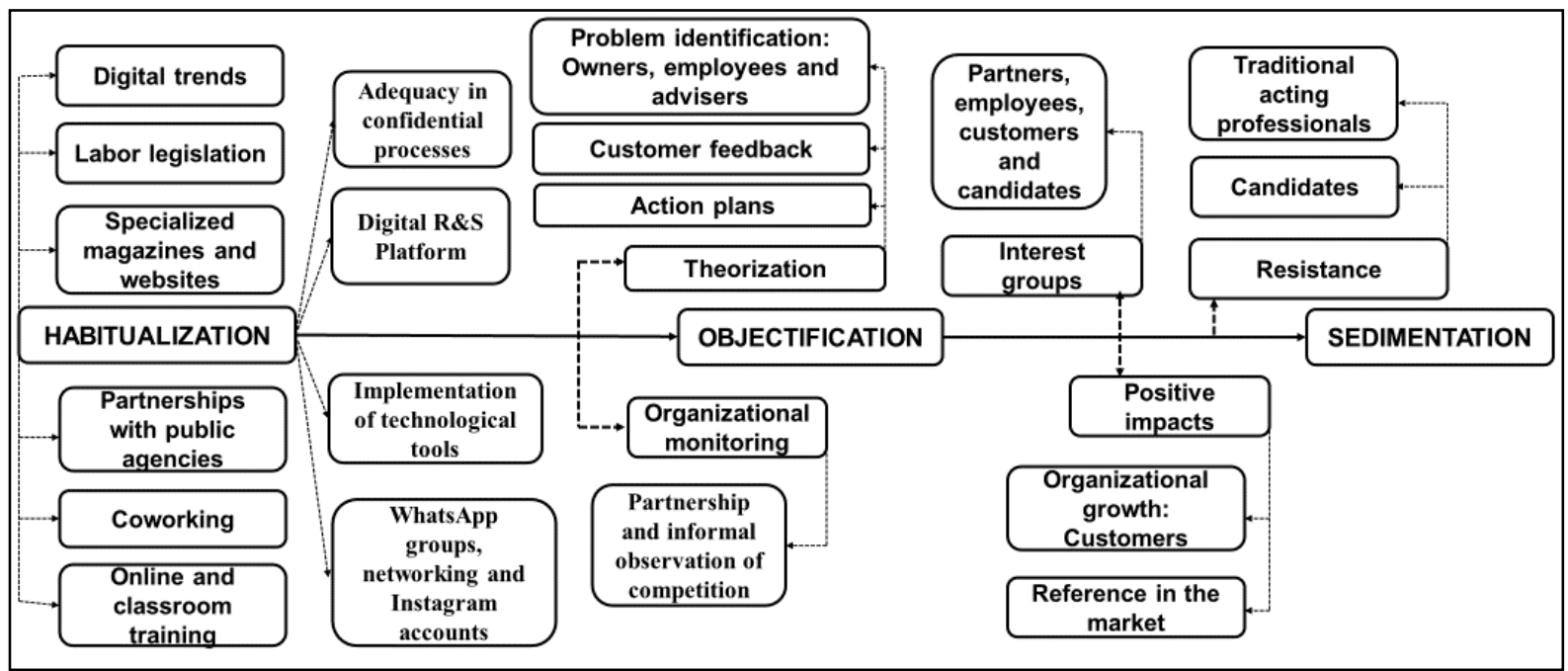

Figure 1: Analytical structure of institutionalization processes in recruitment and selection consultancies (R\&S).

Source: Developed by the authors of Tolbert and Zucker (1999, 2012).

The analysis of the proposed analytical structure allows us to understand that, in the phase of habitualization, recruitment and selection consultancies receive technological environmental stimuli (digital trends), legislation (work), and market forces, demonstrated by the influence of specialized magazines and websites. In general, environmental stimuli led to isomorphic behaviors operationalized in partnerships with public agencies and the use of coworking spaces (mimetic isomorphism), courses, updates and online and face-to-face training (normative isomorphism) and respect for legal labor standards (coercive isomorphism) online

The receipt of environmental stimuli, as well as the organizational reactions of the consultancies of recruitment and selection of people, lead to the adoption of new structural arrangements, organized mainly in a digital environment, specifically with the adequacy of confidential processes to serve customers, acquisition, and implementation of services of digital platforms, as well as participation in WhatsApp groups, networking, and creation of Instagram accounts. In this context, it is worth mentioning that digital transformation, as happens in the consultancies studied, is a chance to improve the commercial performance of companies with limited access to markets and sources of financing (Popović-Pantić, Semenčenko \& Vasilić, 2019). 
DOI: 10.14807/ijmp.v12i5.1445

The implementation of new structural arrangements qualifies these companies to experiment and apply procedures to objectify their business through theorization and interorganizational monitoring, which are superficially applied because recruitment and selection consulting companies establish partnerships restricted to the exchange of information and observation of generic competition practices. On this subject, some of the interviewees ensured that the local market (Sergipe) does not assume a cooperative posture, however, none of them reported an effective initiative to change this scenario, which contributed to the majority of the companies studied being framed in the stages of habitualization and objectification.

On the other hand, these businesses are a little more advanced in terms of theorization processes, as they consider evaluating owners and external advisers to identify broader problems, and the participation of employees, customers, and service providers for guidance and feedback on operational procedures. Thus, this group of agents acts as a platform to receive information and collect ideas from a wide range of stakeholders that contribute to proper planning, as they reveal which supplies and engagement are necessary for the progress of the business (Lehtinena, Aaltonenb \& Rajala, 2019), which results in the elaboration and/or adjustment of action plans.

After partial experimentation of components of the objectification stage, recruitment and selection consultancies advance in the characteristics of institutional sedimentation, especially in the defense of interest groups, represented by clients, employees, candidates, and partners (service providers), these being the main stakeholders for the operation of these businesses.

The identification and action against the resistant behavior of some groups is a flawed and very restricted activity in consultancies, because, except professionals with limited capacity to use digital tools and customers eager to enter the labor market, these companies make no effort to recognize and minimize negative behaviors of these groups. We highlight the perception that the absence of resistance of groups can be the result of the limited attention of managers to these behaviors so that the greater direction to the perceptions and reactions of interest groups can be an instrument for optimization of administrative processes and evolution to the sedimentation stage.

For the sedimentation stage, there is also a growing perception that clients, candidates, and partners (service providers) constitute interest groups, however, the absence of institutional 
DOI: 10.14807/ijmp.v12i5.1445

agents such as government agencies, educational institutions, and parastate entities limits the consolidation and sedimentation of the organizations evaluated.

Finally, organizational growth based on the largest number of clients served and the position of reference in the market is the main positive impact on the consulting business.

\section{CONCLUSIONS}

The lens of institutional theory has been recognized as an important theoretical tool for evaluating organizational practices, as well as the stage of administrative consolidation of organizations. In this context, this research sought, through a qualitative-descriptive study, to analyze the stages of institutionalization, according to the model of Tolbert and Zucker (1999, 2012) in recruitment and selection consulting companies (R\&S) resident in Sergipe, Brazil.

It is concluded, then, that unsatisfactory inter-organizational monitoring, associated with the limited identification of resistance of groups, as well as the inexpressive elaboration of strategies to mitigate the performance of resistance groups are the main obstacles to the sedimentation of consulting companies in recruitment and selection of people.

Consequently, the main limitations of this research are represented by the restricted practice of inter-organizational monitoring, limited participation of different agents (champions)in the processes of theorization, and non-identification of resistance groups in part of the companies surveyed, which limited the analysis of these elements in the process of sedimentation of consultancies.

The results presented in this research do not exhaust the possibilities of analysis on the subject, so new studies may: analyze the role of technological pressures as determinants or influencers of habitualization; to investigate the limiting and potentiating elements of interorganizational monitoring, as well as to investigate the contribution of inter-organizational monitoring to reach the sedimentation phase. In addition, new research may: compare the perceptions of managers, clients, and users to identify the points of resistance and administrative consequences of the resistance of interest groups; evaluate the reasons for the limited performance of government agencies, parastate entities, and educational institutions such as champions of recruitment and selection consultancies. Finally, quantitative studies can correlate the organizational performance of recruitment and selection consultancies with the presence of elements of the stages of habitualization, objectification, and sedimentation.

\section{REFERENCES}


Abeygunasekera, A. W. J. C. (2019). Influence of performance measurements on institutionalizing process improvement initiatives. (Doctor Thesis) - Doctor of Philosophy. Information Systems School, Science and Engineering Faculty, Queensland University of Technology, Queensland, QLT, Australian.

https://eprints.qut.edu.au/132655/1/Ahangama\%20Withanage\%20Janitha_Abeygunasekera_ Thesis.pdf

Aksom, H., Zhylinska, O., \& Gaidai, T. (2020). Can institucional theory be refuted, replaced or modified? International Journal of Organizational Analysis, 28(1), 135-159.

https://doi.org/10.1108/IJOA-02-2019-1666

Altayar, M. S. (2018). Motivations for open data adoption: An institutional theory

perspective. Government Information Quarterly, 35(4), 633-643.

https://doi.org/10.1016/j.giq.2018.09.006

Alvesson, M., Hallett, T., \& Spicer, A. (2019). Uninhibited Institutionalisms. Journal of Management Inquiry, 28(2), 119-127. https://doi.org/10.1590/1984-9260895

Augusto, C. A., Souza, J., \& Cario, S. A. F. (2014). Nova economia institucional: vertentes complementares. Revista Ibero-Americana de Estratégia, 13(1), 93-108.

https://doi.org/10.5585 / riae.v13i1.2036

Balasubramanian, K. (2014). The Significance of Recruitment in an Organization. Global Journal of Finance and Management, 6(8), 735-738. https:/www.ripublication.com/gjfmspl/gjfmv6n8_06.pdf

Bardin, L. (2006). Análise de conteúdo (L. de A. Rego \& A. Pinheiro, Trads.). Lisboa: Edições 70. (Obra original publicada em 1977)

Cancellier, E. L. P.L., Blageski, E. J., \& Rossetto, C. R. (2014). Environmental scanning, strategic behavior, and performance in small companies. JISTEM - Journal of Information Systems and Technology Management, 11(3), 611-628. https://doi.org/10.4301/S180717752014000300006

Cappellari, N., Stefano, S. R., \& Castro, M. (2019). A Institucionalização da

Sustentabilidade na Itaipu Binacional: A Institucionalização da Sustentabilidade Organizacional. Novas edições acadêmicas - 139 pages.

Carpes, A. M., Santos, M. B., Scherer, F. L., Hahn, I. S., \& Oliveira, M. C. S. F. (2015). O uso da teoria institucional nas pesquisas científicas e os tópicos relacionados: uma amostra do panorama mundial. Diálogo, Canoas, 30, 125-143. http://dx.doi.org/10.18316/22389024.15.18

Chan, F. T. S., Chong, A. Y., \& Zhou, L. (2012). An empirical investigation of factors affecting e-collaboration diffusion in SMEs. International Journal of Production Economics, 138(2), 329-344. https://doi.org/10.1016/j.ijpe.2012.04.004

Costa, D. M., Sprenger, K. B., \& Kronbauer, C. A. (2019). Conformidade na Evidenciação do Ativo Imobilizado: Um Estudo sob a Ótica da Teoria Institucional. Reunir: Revista de Administração, Contabilidade e Sustentabilidade, 9(2), 49-61. https://doi.org/10.18696/reunir.v9i2.844

Creswell, J. W. W. (2010). Projeto de pesquisa: métodos qualitativo, quantitativo e misto. 2. ed. Porto Alegre: Bookman, 2010. 
Dequech, D. (2002). The Demarcation between the "Old” and the "New" Institutional Economics: Recent Complications. Journal of Economic Issues, 36(2). https://doi.org/10.2307/4227808

Dimaggio, J., \& Powell, W. (1991). The New Institutionalism in Organizational Analysis. London: University of Chicago Press.

Dimaggio, P. J. \& Powell, W. W. (1983). The iron cage revisited: institutional isomorphism and collective rationality in organizational fields. American Sociological Review, 48, 147160. https://cutt.ly/afV9C9I

Doherty, A.Chen, X., Alexander, N. The franchise relationship in China: agency and institutional theory perspectives. European Journal of Marketing, 48(9/10), 1664-1689. https://doi.org/10.1108/EJM-04-2012-0199

Donadone, J. C., Silveira, F. Z., \& Ralio, V. R. Z. (2012). Consultoria para pequenas e médias empresas: as formas de atuação e configuração no espaço de consultoria brasileiro.

Gestão \& Produção, 19(1), 151-171. https://doi.org/10.1590/S0104-530X2012000100011

Eisenhardt, K. M. (1989). Building theories from case study research. Academy of management review, 14(4), 532-50. https://psycnet.apa.org/doi/10.2307/258557

Fonseca, D. R., Camões, M. R. S., Cavalcante, P. L. C., Lemos, J., \& Palotti, P. (2019). Schools of Government's Roles and Challenges for Institutionalization: A Comparative Study in the Brazilian Federal Public Sector. Revista do Serviço Público, 70(Edição Especial), 71106. https://doi.org/10.21874/rsp.v70i0.1458

Friedland, R., \& Alford, R. R. (1991). Bringing Society Back In: Symbols, Practices, and Institutional Contradictions. In W. W. Powell \& P. J. DiMaggio (Eds.). The new institucionalism in organizational analysis (pp. 232-263). Chicago: The University of Chicago.

Greenwood, R., Oliver, C., Sahlin, K., \& Suddaby, R. (2008). The Sage handbook of organizational institutionalism. London: Sage Publications.

Greenwood, R., Raynard, M., Kodeih, F., Micelotta, E. R., \& Lounsbury, M. (2011). Institutional Complexity and Organizational Responses. The Academy of Management Annals, 5(1), 317-371. https://doi.org/10.5465/19416520.2011.590299

Greenwood, R., Suddaby, R., \& Hinings, C. R. (2002). Theorizing Change: The Role of Professional Associations in the Transformation of Institutionalized Fields. Academy of Management Journal, 45(1). https://doi.org/10.5465/3069285

Haack, P. (2012). Legitimacy in institutional theory: Three essays on social judgments in a globalized world. (Doctor Thesis) - Doctorate in Philosophy in Business Administration). University of Zurich, Switzerland.

https://www.zora.uzh.ch/id/eprint/72272/1/20121220204659_merlin-id_7766.pdf

Hague, P. \& Hague, N. (2016). Customer Satisfaction Survey: The customer experience through the customer's eyes. London: Cogent Publication.

Haider, A. (2014). Business Technologies in Contemporary Organizations: Adoption, Assimilation and Institucionalization. South Australia: Business \& Management Books.

Hsu, P. L., Maccari, E. A., Mazieri, M. R., \& Storópoli, J. E (2018). A bibliometric review of institutional theory on higher education institutions. Future Studies Research Journal, 10(3), 383-401. https://doi.org/10.24023/FutureJournal/2175-5825/2018.v10i3.384 
Kauppi, K. (2013). Extending the use of institutional theory in operations and supply chain management research: Review and research suggestions. International Journal of Operations \& Production Management, 33(10), 1318-1345. https://doi.org/10.1108/IJOPM-10-2011-0364

Khadka, K., Maharjan, S. (2018). Customer satisfaction and customer loyalty. (Doctor Thesis) - Doctorate in Business Management - Centria University of Applied Sciences, Talonpojankatu, Finland. https://core.ac.uk/download/pdf/161421179.pdf

Kulak, C. M., Stefano, S. R., \& Kühl, M. R. (2019). Institucionalização de Práticas de Sustentabilidade. Reuna, 24(2), 67-88. http://dx.doi.org/10.21714/21798834/2019v24n2p67-88

Lehtinena, L., Aaltonenb, K., \& Rajala, L. (2019). Stakeholder management in complex product systems: Practices and rationales for engagement and disengagement. Industrial Marketing Management, 79, 58-70. https://doi.org/10.1016/j.indmarman.2018.08.011

León, I., Martinez, J. (2011). The influence of organizational structure on organizational learning. International Journal of Manpower, 32, 537-566. https://doi.org/10.1108/01437721111158198

Li, F., Ding, D. Z. (2013). The effect of institutional isomorphic pressure on the internationalization of firms in an emerging economy: evidence from China. Asia Pacific Business Review, 19(4), 506-525. https://doi.org/10.1080/13602381.2013.807602

Mahanani, K. Y., Hariadi, B., \& Roekhudin, R. (2020). The Institutionalization of Remuneration (A Case Study at the University X). Journal of Accounting and Business Education, 4(2). http://journal2.um.ac.id/index.php/jabe/article/view/7140/5319

Merriam, S. (1998). Qualitative Research and Case Study Applications in Education. San Francisco: Jossey-Bass.

Meyer, J. W., \& Rowan, B. (1977). Institutionalized Organizations: Formal Structure as Myth and Ceremony. American Journal of Sociology, 83(2), 340-363, 1977.

https://www.jstor.org/stable/2778293

Meyer, J. W., \& Scott, W. R. (1983). Organizational Environments: Ritual and Rationality Beverly Hills: Sage.

Meyer, J. W., \& Scott, W. R. (1983). Organizational Environments: Ritual and Rationality. Beverly Hills: Sage, 1983.

Miemczyk, J. (2008). An exploration of institutional constraints on developing end-of-life product recovery capabilities. International Journal of Production Economics, 115(2), 272-282. https://doi.org/10.1016/j.ijpe.2008.04.013

Motke, F. D., Ravanello, F. S., \& Rodrigues, G. O. (2016). Teoria Institucional: um Estudo Bibliométrico da Última Década na Web of Science. Contextus - Revista Contemporânea de Economia e Gestão, 14(2), 63-86. https://doi.org/10.19094/contextus.v14i2.792

Mutai, E. K., Cheruiyot, Thomas K., \& Kirui, J. K. (2015). Impact of participatory management on employee performance: a case of moi university. (2015). Global journal of commerce\& management perspective, $4(2), 54-59$.

https://www.longdom.org/articles/impact-of-participatory-management-on-employeeperformance-a-case-of-moi-university.pdf

Nascimento, S., Penz, D., Amorim, B. C., Mazon, G., \& Rossetto, C. R. (2014). Abordagens da produção científica em Administração publicada na base Scopus à luz da Teoria 
Institucional, de 2000 a 2013. Revista Eletrônica de Estratégia \& Negócios, 7(2), 118-147. http://www.portaldeperiodicos.unisul.br/index.php/EeN/article/view/1945/1685

Neuman, W. L. (2013). Social research methods: qualitative and quantitative approaches. 7.ed. Harlow: Pearson Education.

Neves, F. R., \& Gómez-villegas, M. (2020). Reforma Contábil do Setor Público na América Latina e Comunidades Epistêmicas: Uma Abordagem Institucional. Revista de Administração Pública, 54(1), 11-31. http://dx.doi.org/10.1590/0034-761220180157x

Oksanen, R. (2018). New technology-based recruitment methods. Dissertation (Master in Management and Organization). Tampere: University of Tampere, Faculty of Management. Available: https://core.ac.uk/download/pdf/250153195.pdf

Owusus-Ansah, S., \& Nyarko, K. S. (2014). Leveraging information technology (IT) in recruitment and selection processes- A comparative study. International Journal of Network and Communication Research, 2(1), 16-44. http://www.eajournals.org/wpcontent/uploads/Leveraging-Information-Technology-It-In-Recruitment-and-SelectionProcesses-A-Comparative-Study.pdf

Palthe, J. (2014). Regulative, Normative, and Cognitive Elements of Organizations: Implications for Managing Change. Management and Organizational Studies, 1(2), 2014. https://doi.org/10.5430/mos.v1n2p59

Pimentel, T. D., Carvalho, F. C. C., \& Pimentel, M. P. C. (2019). O Processo de Institucionalização das Estruturas Formais de Investigação em Turismo (EFIT) no Brasil.

Revista Brasileira de Pesquisa em Turismo, 13(3), 16-35.

https://doi.org/10.7784/rbtur.v13i3.1493

Popović-Pantić, S., Semenčenko, D., Vasilić, N. (2019). The influence of digital transformation on business performance: Evidence of the women-owned companies. Original Scientific Paper UDK, 397 - 441. https://doi.org/10.5937/EKOPRE1908397P

Raynard, M., Johnson, G., \& Greenwood, R. (2014). Institutional Theory and Strategic Management. In book: Advanced Strategic Management Edition: 3rdPublisher: Palgrave Macmillan Editors: M. Jenkins, V. Ambrosini, N. Mowbray.

Rees, G., \& Smith, P. (2017). Strategic Human Resource Management: An international perspective. SAGE Publications, Business \& Economics, 616 pages.

Rezende, A. J., Guerreiro, R., \& Dalmácio, F. Z. (2012). Um estudo sobre o processo de desinstitucionalização das práticas contábeis de correção monetária em empresas brasileiras. Revista Contabilidade \& Finanças, 23(58), 33-51. https://doi.org/10.1590/S151970772012000100003

Rizal, O., Suhadak, M. K. (2017). Analysis of the influence of external and internal environmental factors on business performance: a study on micro small and medium enterprises (MSMES) of food and beverage. Russian Journal of Agricultural and SocioEconomic Sciences, 66(6), 47-56. https://doi.org/10.18551/rjoas.2017-06.05

Rodríguez-Sánchez, J. L., Montero-Navarro, A., \& Gallego-Losada, R. (2019). The Opportunity Presented by Technological Innovation to Attract Valuable Human Resources.

Sustainability, 11. https://doi.org/10.3390/su11205785

Roth, Steffen (Ed.) (2015). Non-technological and non-economic innovations:

Contributions to a theory of robust innovation. München: Akademischer Verlag München. https://papers.ssrn.com/sol3/papers.cfm?abstract_id=2531772 
Russo, D., Parisi, C., Megliorini, E., \& Almeida, C. B. (2012). Evidências de elementos de institucionalização do Balanced Scorecard na obra "A estratégia em ação": um olhar baseado na teoria institucional. Revista Contabilidade \& Finanças, 23(58), 7-18. https://doi.org/10.1590/S1519-70772012000100001

Sarkis, J., Zhu, Q., \& Lai, K. (2011). An organizational theoretic review of green supply chain management literature. International Journal of Production Economics, 130(1), 115. https://doi.org/10.1016/j.ijpe.2010.11.010

Scott, W. R. (2014). Institutions and Organizations: Ideas, Interests, and Identities (4a). London: Sage Publications Ltd.

Seyfried, M., Ansmann, M. \& Pohlenz, P. (2019). Institutional isomorphism, entrepreneurship and effectiveness: the adoption and implementation of quality management in teaching and learning in Germany. Tertiary Education and Management, 25, 115-129. https://doi.org/10.1007/s11233-019-09022-3

Silva, F. R., \& Crubellate, J. M. (2016). Complexidade Institucional: um estudo bibliométrico na publicação recente em teoria institucional. Revista Eletrônica de Ciência Administrativa, 15(2), 116-132. https://doi.org/10.21529/RECADM.2016009

Soeiro, T. M., \& Wanderley, C. A. (2019). A Teoria Institucional na Pesquisa em Contabilidade: Uma Revisão. Organizações \& Sociedade, 26(89), 291-316. https://doi.org/10.1590/1984-9260895

Sornberger, G. P.; Hoppen, N., \& Rigoni, E. (2016). The institutionalization process of governance in a Virtual Business Community: a case study. CONF-IRM 2016 Proceedings. 13. https://aisel.aisnet.org/confirm2016/13

Subramanian, K. R. (2018). The connection between your employees and customers. Journal of Advance Research in Business Management and Accounting, 4(8). https://nnpub.org/index.php/BMA/article/download/28/17

Suddaby, R. (2010). Challenges for institutional theory. Journal of Management Inquiry, 19(1), 14-20. https://doi-org.ez20.periodicos.capes.gov.br/10.1177\%2F1056492609347564

Thornton, P. H., \& Ocasio, W. (1999). Institutional Logics and the Historical Contingency of Power in Organizations: Executive Succession in the Higher Education Publishing Industry, 1958- 1990 1. American Journal of Sociology, 105(3), 801-843.

https://doi.org/10.1086/210361

Thornton, P. H., Ocasio, W., \& Lounsbury, M. (2012). The institutional logics perspective: A new approach to culture, structure and process. Oxford: Oxford University Press.

Tolbert, P. S., \& Zucker, L. G. (1983). Institutional sources of change in the formal structure of organizations: the diffusion of civil service reform, 1880-1935. Administrative Science Quaterly, 30, 22-39.

https://digitalcommons.ilr.cornell.edu/cgi/viewcontent.cgi?article=1132\&context=articles

Tolbert, P. S., \& Zucker, L. G. (2012). A institucionalização da teoria institucional. In: Clegg, S., Hardy, C., \& Nord, W. Handbook de estudos organizacionais: Modelos de análise e novas questões em estudos organizacionais. São Paulo: Atlas, 2012.

Tolbert, P.S., \& Zucker, L.G. (1999). A institucionalização da Teoria Institucional. In: Clegg, S. Handbook de estudos Organizacionais (pp. 196-218). São Paulo: Atlas.

Vailatti, J. L., Rosa, F. S., Rodrigues Vicente, E. F. (2017). Institutional theory applied to management accounting: analysis of theoretical and methodological contribution of 
international publications occurred in the 2006-2015 period. Revista Catarinense da Ciência Contábil, 16(47), 91-104.

http://revista.crcsc.org.br/index.php/CRCSC/article/download/2263/1924

Wisdom, J. P., Chor, K. H., Hoagwood, K. E., \& Horwitz, S. M. (2014). Innovation adoption: a review of theories and constructs. Administration and policy in mental health, 41(4), 480-502. https://doi.org/10.1007/s10488-013-0486-4

Yang, Z., \& Su, C. (2014). Institutional theory in business marketing: A conceptual framework and future directions. Industrial Marketing Management, 43, 721-725. https://doi.org/10.1016/j.indmarman.2014.04.001

Yawar, S. A., \& Kauppi, K. (2018). Understanding the adoption of socially responsible supplier development practices using institutional theory: Dairy supply chains in India. Journal of Purchasing and Supply Management, 24(2), 164-176.

https://doi.org/10.1016/j.pursup.2018.02.001

Yilmaz, A. K., Flouris, T. (2017). Corporate Risk Management for International Business. Springer (Digital Book).

Yin, R.K. (2015). Estudo de caso: planejamento e métodos. 5.ed., Porto Alegre: Bookman, 2015.

Zucker, L. G. (1977). The role of institutionalization in cultural persistence. American Sociological Review, 42, 726-743. https://cutt.ly/pfV3q8L 